\author{
Nebojša Lujanović \\ nlujanovic@hotmail.com
}

\title{
Performativna snaga imena u zbirci priča Inšallah Madona, inšallah Miljenka Jergovića
}

\begin{abstract}
ABSTRAKT. Lujanović Nebojša, Performativna snaga imena u zbirci priča „Inšallah Madona, inšallah" Miljenka Jergovića (The Performative Potential of Names in Miljenko Jergović's Collection of Stories Inšallah Madona, inšallah). „Poznańskie Studia Slawistyczne" 4. Poznań 2013. Adam Mickiewicz University Press, pp. 89-101. ISBN 978-83-2322525-6. ISSN 2084-3011.

The names play a main role in understanding of Miljenko Jergović's literary works and it is argued through analysis of collection of stories called Inšallah Madona, inšallah. The names have their history, they describe and determine actors, and function as axioms with initial stabile meaning. By decoding of related code, new complex components of semantic field of the name as symbol are revealed to us. In chosen text, the names operate as curse in form of general principle. Through curse as a main motive, it is implied performative dimension of the names which symbolize pain or misery, evoke tragedy and in the end fulfil inscribed curse.
\end{abstract}

Keywords: name, symbol, code, decoding, curse, performative

\section{Uvod}

U južnoslavenskim književnostima značenje osobnog imena (uključujući značenje prezimena, nadimka i ostalih mogućih varijacija antroponima koji su vezani uz pojedinu osobu) može biti vrlo zanimljivo u interpretaciji književnih djela. U njima se imena često referiraju na etničku ili vjersku pripadnost, imaju svoju povijest, opisuju i determiniraju aktere, ali i na metaforičkoj razini važan su element interpretacije književnog djela kao cjeline. U tom se smislu ukazuje potreba za opsežnijom i sustavnijom analizom imena u spomenutim književnostima. Ovaj je rad ujedno i uvod u dugoročno istraživanje kojim bih pokušao otvoriti raspravu i cijeli niz pitanja u toj sferi proučavanja južnoslavenskih književnosti. U kontekstu 
takve književnosti koja pripada isprepletenim kulturalnim paradigmama i hibridnim konstrukcijama ime može funkcionirati kao aksiom. Ova mu analiza pripisuje određenu početnu vrijednost i stabilno značenje (koje će teško dovesti u pitanje i najradikalnije konstruktivističke perspektive) na kojem se onda, uzimajući u obzir ostale elemente strukture i društveno-kulturni kontekst, umnažaju moguće interpretacije. Za početak, ime možemo proučiti kao znak koji je strukturiran kao niz u kojem je svako značenje označitelj za jedno novo označeno. Tako ćemo doći do jedne zanimljive interpretacije o povezanosti imena i prokletstva na semantičkoj razini, nakon čega su uočljive naznake performativne dimenzije imena. Zbirka priča Miljenka Jergovića pod nazivom Inšallah Madona, inšallah podatan je tekst za takvu vrstu pristupa jer u njemu imena nose ključni semiotički potencijal za razumijevanje djela uopće.

Da bismo krenuli u složen proces raspoznavanja svih mogućih silnica koje su bitne za ovakav način interpretacije, potrebno je pristupiti složenom tkivu teksta onako kako to sugerira semiotika književnosti. Takav pristup nalaže tretman teksta kao skupa signala koji putem nekog medija stiže od pošiljatelja prema primatelju u određenom kodu ili skupu kodova. Suvremena semiotika također predlaže da se tekst ne shvaća kao kruta stabilna struktura, nego kao diskurz koji je promjenjiv, dinamičan $i$ ispunjen proturječjima ${ }^{1}$. Dakle, kako bismo valjano interpretirali odabrani tekst, potrebno je sagledati mnoštvo znakova iz teksta unutar koda kojim su ti znakovi organizirani, a u koji tek treba proniknuti. Osim toga nakon te raščlambe tekst treba sagledati i kao cjelinu. Pojam teksta jednak je pojmu znaka. Tekst je cjelovit znak, kao što je također i skup znakova ${ }^{2}$. Ako proniknemo u karakteristike imena kao znakova te u kod kojim su organizirani, onda će se završni dio analize odnositi na pokušaj detektiranja značenja teksta kao cjeline, tj. kao jednog znaka.

Iz zadanog semiotičkog kuta promatranja, dekodiranje bilo kojeg sustava znakova zahtijeva određenu kompetenciju analitičara ili čitatelja. Ona se može sastojati od poznavanja teorijskih postavki, poznavanja autorovog opusa i mjesta unutar određenog korpusa, ali svakako i društveno-kulturnog konteksta unutar kojeg se realizira interpretacijski potencijal teksta. Jedno od osnovnih polazišta semiotike činjenica je da smo okruženi

\footnotetext{
${ }^{1}$ M. Beker, Semiotika književnosti, Zagreb 1991, str. 154.

2 J. Lotman, Struktura umjetničkog teksta, prev. S. Veršić, Zagreb 2001, str. 30.
} 
znakovima obuhvaćenima različitim kulturalnim kodovima, pa kako je potrebna kompetencija za čitanje npr. prometnih znakova tako je potrebna i za snalaženje u književnom tekstu ${ }^{3}$. U tom su smislu od iznimne koristi osnovna saznanja semiotike od kojih će neka biti izložena prije same interpretacije. Semiotika nam koristi za raščlambu struktura predstavljanja koje su kodirane unutar logike nekog šireg sustava (kao što je u našem slučaju tekst) ${ }^{4}$. Time nam je omogućeno čitanje ispod (imena kao aksiomi, njihovo početno značenje) i iznad razine znaka (imena kao mehanizam prenošenja prokletstva) te međusobnog odnosa znakova unutar sustava (imena kao simboli koji upućuju na jedno značenje sustava/teksta - tragedija kao nasljedna kategorija). Cilj ovog rada nije uspostaviti jednoznačno tumačenje uloge imena uočljivo na prvoj razini istraživanja, nego se povoditi sugestijom Rolanda Barthesa. Njega ne zanima ono što se predstavlja i kako se predstavlja, nego pronalazak novih načina čitanja. Barthes predlaže da ne tragamo za značenjem, nego za bljeskovima „,skrivenog", "Zato u ovoj analizi nećemo tumačiti znak, njegovo opće značenje i mehanizam njegovog djelovanja, nego istraživati skrivene i neosvijetljene dijelove u polju međuovisnosti tih znakova.

\section{Od simbola do koda - teorijski uvod}

U svrhu rasvjetljavanja osnovnih pojmova koji će biti korišteni u ovoj analizi (znak, simbol, kod, diskurz) bit će ponuđene samo osnovne definicije. U odabranom tekstu ime funkcionira kao simbol, vrsta znaka s pripadajućim mnogostrukim značenjima koja se mogu detektirati samo dekodiranjem pripadajućeg koda. Govorimo o tri vrste znaka: ikona, indeks i simbol (gdje je simbol najsloženiji oblik s obzirom na proizvoljnost i društvenu uvjetovanost svog značenja). Znak se uobičajeno razlaže na dvije komponente: označitelj (slika ili riječ) i označeno (pojam, predodžba). Tek je suvremena teorija inzistirala na dodatnim vrlo važnim komponentama znaka, kao što su: referent, kod i kontekst ${ }^{6}$.

\footnotetext{
${ }^{3}$ M. Beker, op. cit., str. 12-14.

${ }^{4}$ P.P. Trifonas, Barthes $i$ carstvo znakova, prev. D. Telećan, Zagreb 2002, str. 9.

${ }^{5}$ Ibidem, str. 15 .

${ }^{6}$ M. Beker, op. cit., str. 154.
} 
Za razumijevanje simbola u kontekstu ovog rada slijedit ću dva tumačenja koja sažima Vladimir Biti u svom pojmovniku. Jedno je Tzvetane Todorove po kojem se simbol upotrebljava u slučaju kada nešto što je prisutno priziva nešto što je odsutno, ali kojeg nikad ne priziva u cijelosti. Označitelj se trsi reproducirati neka obilježja označenoga, ali u tome nikada do kraja ne uspijeva. To je bitno zbog implikacije da se iza simbola imena u odabranom tekstu umnažaju moguća značenja koja je nemoguće do kraja iscrpiti, nego negdje povući proizvoljnu granicu donekle funkcionalnu u okviru iščitavanja. Drugo tumačenje je ono Umberta Eca po kojem simbol nije neki statičan oblik, nego dinamičan način upotrebe. Mi ne definiramo konačno značenje simbola, nego upućujemo na simbolički potencijal imena kojeg ćemo u samo jednom dijelu iscrpiti. Za Eca se u svemu može pronaći simbolički potencijal ako tragamo za njime, sve se može pročitati na simbolički način? ${ }^{7}$.

Pitanje koda prilično je složeno i u određenoj mjeri uvjetuje razumijevanje teksta. Kod je sustav u koji su uklopljeni elementi teksta, a koji je specifičan po određenim pravilima kojima je ograničen taj skup elemenata $^{8}$. S jedne strane imamo kod koji zadaje čitatelj, uz kod koji proizvodi tekst i koji se ne mora poklapati s autorovom intencijom. S druge strane imamo čitatelja ili interpretatora sa svojim kodom. Za shvaćanje teksta, tj. poklapanje poruke kakvu odašilje tekst i kakvu je prima čitatelj, nužna su poklapanja ili podudaranja ta dva koda. Ako i postoje preduvjeti za takvo nešto, treba očekivati puno složeniju situaciju u konkretnim slučajevima. Naime tekst može proizvoditi kod, potvrđivati kod ili pak kršiti kod koji mu pokušavamo nametnuti od strane autora ili čitatelja. Tu se zaplićemo u mnoštvo mogućnosti, uhvaćeni u dijalektičku igru različitih silnica ${ }^{9}$. Moguće je definirati značenje imena kao simbola s obzirom na prividno statičnu ulogu u tekstu. Međutim, kada se to značenje stavi u kontekst Jergovićevih taktika poigravanja stabilnošću identiteta, a zatim u društveno-kulturni kontekst sukoba etničkih identiteta, kodovi se umnažaju do neslućenih razmjera.

Ono što konkretno pokušava ova analiza jest odrediti semantičko polje imena kao simbola. Prema definiciji Algirdasa Juliena Greimasa, seman-

\footnotetext{
${ }^{7}$ V. Biti, Pojmovnik suvremene književne i kulturne teorije, Zagreb 2000, str. 500-501.

${ }^{8}$ J.D. Johansen, S.E. Larsen, Uvod u semiotiku, prev. S. Grgas, Zagreb 2000, str. 16.

${ }^{9}$ T. Eagleton, Književna teorija, prev. M. Pervan-Plavec, Zagreb 1987, str. 139.
} 
tičko polje je skup elemenata smisla koji pripadaju jednom pojmu ${ }^{10}$. To bi značilo da pojedino ime s obzirom na svoju artikulaciju unutar teksta ima određeni skup značenja koji je uz njega vezan, a ova će interpretacija pokušati istaknuti jedan poseban dio tog skupa koji se odnosi na pitanje prokletstva kao glavnog motiva odabranog teksta. Posebnim tretmanom imena od strane pripovjedača u tekstu skrenuta je pažnja da se radi o značajnim mjestima. Uostalom, znakovi bi trebali imati prepoznatljiv semiotički potencijal (na pripovjedaču je da koristi neku od nepreglednih tehnika naglašavanja ili upućivanja, da bi se realizirala ta prepoznatljivost) kako bi se čitatelj/referent zaustavio, prepoznao znak i dekodirao $\mathrm{ga}^{11}$. U skladu sa svim navedenim, treba primijeniti i modificiranu definiciju diskurza. Diskurz je u ovom značenju semiotička radnja koja smješta značenje u vremensko-prostornu situaciju gdje netko za nekoga proizvodi značenje $^{12}$. Vremensko-prostorna komponenta upućuje na društveno-kulturni kontekst koji u Jergovićevom slučaju umnaža moguća značenja koja će biti samo naznačena jer njihovo iscrpno iščitavanje izlazi iz okvira ovog rada.

\section{Ime - formirana kletva u obliku općeg principa}

Ako iz polazišta semiotike imena promatramo kao simbole, a tkivo Jergovićevog teksta kao mrežu značenja tih simbola kojom dominira određeni kod u koji tek treba proniknuti, uočljiv je jedan dominantan način tretiranja imena. Naime osobna imena kao da se odvajaju od subjekta, njihova snaga nadilazi identitet uz koji su vezana. Očito je da ta osobna imena izlaze iz okvira koji im zadaje kategorija „osobnog” i u tom iskoraku kletva koja je upisana u ime nalazi se u najvišem stupnju djelotvornosti. Dakle ime je samo posredno vezano uz subjekt, više ne upućuje na njega, nego na šire značenje. To značenje je najčešće jedan od oblika tragedije (specifična bolest ili oblik pogibije) koji je poopćen do statusa općeg principa po kojem funkcionira svijet ukoliko se ispune određeni uvjeti.

Konkretno to možemo pokazati na primjeru iz priče Misir. U toj se priči ponavlja fraza „Ne daj ti Bože Ivana Zavišinog sna”. Ponavljaju frazu

\footnotetext{
${ }^{10}$ M. Beker, op. cit., str. 152.

${ }^{11}$ J.D. Johansen, S.E. Larsen, op. cit., str. 43.

${ }^{12}$ Ibidem, str. 322.
} 
i oni koji ne znaju tko je Ivan Zaviša, niti su ga ikada poznavali, što ih ne ometa u tome da jasno dekodiraju značenje te fraze. Kletva je metafora za čovjeka koji je imao sve, ali u tom obilju nije bio niti zaštićen, niti zadovoljan. Kletva bi se mogla prevesti ovako: Ne daj ti Bože da imaš sve oko sebe, a opet nemaš ništa što te usrećuje. U priči je to strašna kletva zbog koje se nerado i sa zebnjom spominje dotično ime, i to u obliku negacije kako bi se ublažio taj strah ${ }^{13}$. Kasnije je razvojem priče pojašnjeno da se radi o plemiću koji je živio sam u velikoj vili, naslutivši sudbinu koja će ga spojiti s izgubljenim dječakom kojem su Misirci oteli majku, a on dječaka sahranio negdje oko te ogromne kuće. Ali kao da taj dio geneze imena nije niti važan. Kako tvrdi Judith Butler ${ }^{14}$, imena imaju povijest koja je ponovno evocirana i uspostavljena neprestanim ponavljanjem imena. $\mathrm{Na}$ taj je način povijest zarobljena u imenu i to je ona sedimentacija koja daje snagu tom imenu.

Ovim primjerom naznačena je dimenzija interpretacije u kojoj ime kao označitelj dobiva nove konotacije, nove modifikacije označenog. Njegovo se semiotičko polje proširuje, a interpretator se suočava s dva problema - problem uslojavanja interpretativnih mogućnosti i problem određivanja granice sagledavanja tih mogućnosti. Kao što napominje Barthes, jedan označitelj uobičajeno ima više označenih, ali negdje je potrebno povući granicu. Odluka da se zaustavimo na određenom mjestu ili na određenoj razini, potpuno je proizvoljna (proizašla iz proizvoljnih kriterija kojima argumentiramo zašto baš granica na tom mjestu), što dodatno ide u prilog konstataciji o arbitrarnosti svakog značenja koje izvodimo. U tom izvođenju, nastavlja Barthes, što se više držimo površine, to je značenje koje definiramo univerzalnije i oko njega postoji veći konsenzus. Što idemo dublje i u detaljniju analizu, to će zaključci biti specifičniji ${ }^{15}$.

Zacijelo je iskorak u detaljniju analizu, a time i manje univerzalno definirano značenje imena, daljnja interpretacija imena kao kletve $u$ formi općeg principa koji, kako ćemo vidjeti u idućem poglavlju, ima i performativnu dimenziju. Time se razotkriva bogatstvo ove zbirke priča koju, kao i svaki umjetnički tekst, obilježava bogat semantički potencijal. Prema Ju-

\footnotetext{
${ }^{13}$ M. Jergović, Inšallah Madona, inšallah, Zagreb 2004, str. 225.

${ }^{14} \mathrm{~J}$. Butler, Excitable speech - a politics of the performative, New York 1997, str. 36.

${ }^{15}$ R. Barthes, Književnost, mitologija, semiologija, prev. I. Čolović, Beograd 1979, str. 125-126.
} 
riju M. Lotmanu, općenito je specifičnost umjetničkog teksta da sugerira mnogostruke mogućnosti interpretacije u kojima svaki čitatelj može pronaći za sebe odgovarajuću modifikaciju značenja. Tu se, naravno, javlja problem kompetencije čitatelja - on otkriva u tekstu onoliko koliko može i želi ${ }^{16}$. Njegovo htijenje u ovom slučaju bit će povezano sa sposobnošću da se dekodira kod unutar kojeg funkcioniraju imena kao simboli prokletstva koja prenose. Kod koji funkcionira prema tom motivu prokletstva kao motivom koji dominira u našoj interpretaciji teksta uspostavlja vanjske okvire dopustivih tumačenja. Da se pozovemo na Lotmana, suvišno je govoriti o jednom mogućem značenju simbola ili teksta, kao i o nepreglednim mogućnostima tumačenja gdje je svatko u pravu. Rješenje se nalazi negdje u sredini - mi možemo govoriti o ukupnosti dopustivih značenja, tj. o mogućnosti više interpretacija, ali u određenim okvirima ${ }^{17}$.

Još je jedan slikovit primjer koji potkrepljuje tezu o imenu kao općem principu. U priči Mekteb ponavlja se fraza „Omere, što se ne utopi”. Ona je postala pučka poslovica koju narod ponavlja kao frazu, imajući na umu nevolje iz svoje sadašnjosti, bez saznanja o tome kako i prema kome je nastala ta kletva. S tim općim značenjem (sintagma čija se uporabna vrijednost svodi na pokušaj neutraliziranja tragedije), frazu ponavljaju akteri modificirajući njenu primjenu u svojim svakidašnjim uvjetima. Izvorno, kletva se veže uz legendu o dječaku koji je pao s mostarskog mosta u rijeku Neretvu. Svi su strahovali za njegov život, dječak je ipak na kraju preživio, ali je sudbina valjda zbog kozmičke ravnoteže posljedica uredila da se te godine vrijeme okrene naopako i obruši na stanovnike grada. Sada to oni izgovaraju svaki put kada ih zadesi neko nevrijeme kako bi skinuli sa sebe nevolju ${ }^{18}$. U ovom je kontekstu ime princip po kojem je uređen svijet: podrazumijeva uzroke, okolnosti i posljedice koje se mogu pojaviti (nevrijeme, bolest, smrt). Izgovaranje imena može voditi u dva smjera - ili prizivanju tih posljedica ili njihovom izbjegavanju.

Gledajući aspekte imena kao simbola s određenim funkcijama unutar koda koji zadaje pripovjedač u odabranom tekstu, možemo izvesti zaključak kako navedena imena nailaze na primjenu u sva tri tipa značenja koja

\footnotetext{
${ }^{16}$ J. Lotman, op. cit., str. 32.

${ }^{17}$ Ibidem.

${ }^{18}$ M. Jergović, op. cit., str. 413-418.
} 
se, prema V.A. Nikonovu, mogu izvesti. Kako njegovu podjelu navode (i dijelom modificiraju kada je u pitanju terminologija) Lewis Bagby i Pavel Sigalov ${ }^{19}$, tri su tipa značenja imena: etimološko, uporabno i društveno značenje. Etimološko značenje odnosi se na podudaranje korijena imena s nekim drugim pojmom koje ima određeno značenje (jedan od likova nosi ime Gurbet, izvedenicu iz turcizma koja znači osamljenik) ${ }^{20}$. Uporabno se značenje može prevesti kao ono značenje koje ime artikulira u konkretnim uvjetima svakodnevnom upotrebom (Jilduza iz istoimene priče dobila je ime prema zlokobnoj zvijezdi koja je sjala za vrijeme tragedije njenog oca; ali nakon toga zlokobnost će se konkretizirati tijekom njenog života u kojem je provela neko vrijeme prerušena u muškarca; s malom modifikacijom Jilduza/Jilduz, to ce ime postati i simbol tragedije koja proizlazi iz podvojenosti) $^{21}$. Društveno značenje je simboličko značenje determinirano kroz zajedničku povijest u određenoj kulturi. Iako ne toliko često, pojavljuje se u slučaju kada imena prerastaju u modifikaciju kletve kao općeg principa zajednice (u frazi „Ne daj ti Bože Ivana Zavišinog sna” ime poprima specifično značenje poopćeno na cijelu zajednicu).

\section{O prokletstvu i performativnoj dimenziji imena}

Performativ je pojam koji potječe od vrlo često upotrebljavane diobe iskaza koju je formulirao John L. Austin. On je iskaz podijelio na konstativ i performativ. Konstativ je onaj iskaz koji samo tvrdi ili opisuje, stoga može biti točan ili netočan. Performativ je iskaz koji ne upućuje na nešto izvan sebe, on kreira ili uspostavlja stanje. On ne opisuje radnju, nego je izvodi; prema tome ne može biti točan ili netočan. Onog trenutka kada je izgovoren, on je istinit u tom smislu što potvrđuje i izvodi ono na što se referira. Takvi su iskazi npr. obećajem, potvrđujem, kunem se, uzimam (na vjenčanju ${ }^{22}$. Takve iskaze možemo proučavati u književnosti i izvan nje

${ }^{19}$ L. Bagby, P. Sigalov, The semiotics of names and naming in Tolstoj's „The Cossacks”, „The Slavic and East European Journal” vol. 31, br. 4, 1987, str. 473-489.

${ }^{20}$ M. Jergović, op. cit., str. 5-14.

${ }^{21}$ Ibidem, str. 15-46.

${ }^{22}$ K. Peternai, Učinci književnosti - performativna koncepcija pripovjednog teksta, Zagreb 2005, str. 17. 
jednakim tretmanom. Izvan književnosti, uz takve je iskaze obično vezan i institucionalni ili dogovoreni niz okolnosti ili pratećih konvencija (kao u slučaju spomenutog vjenčanja). Ako gledamo književno djelo kao cjeli$\mathrm{nu}$, tj. jedan cjelovit iskaz, onda ono ukupno ima performativnu dimenziju jer ne opisuje, nego kreira jedan novi svijet/osjećaj/atmosferu/poruku.

Austin dalje definira tri aspekta od kojih se sastoji performativno polje vezano uz neki iskaz. Tu su: lokucija (sam čin kazivanja), ilokucija (čin izveden kazivanjem, dimenzija uvjetovana društvenim konvencijama) i perlokucija (učinak ostvaren takvom vrstom iskaza) ${ }^{23}$. Iako je Austin veći dio svoje analize usmjerio na ilokucijski dio performativnog polja (onaj institucionalni ili konvencionalni dio oko kojeg mora postojati društveni konsenzus kao preduvjet realiziranju performativa), njegova je teorija funkcionalno polazište za analizu imena kao potencijalnih performativnih iskaza kojima se u odabranim tekstovima realizira ili potvrđuje određena radnja/ stanje. Prema spomenutim komponentama, naša bi analiza onda bila usredotočena na perlokuciju, tj. ono što se konkretno ostvaruje imenom kao performativnim iskazom.

Butler upozorava da bi trebalo performativne iskaze analizirati na dvije razine. Na strukturalnoj razini trebalo bi analizirati kako takvi iskazi koegzistiraju s ostalim elementima strukture teksta i koja je njihova uloga u toj strukturi. Na semantičkoj razini iskaza trebalo bi iščitavati moguće značenje takvog iskaza i njegovu ulogu u semantičkom polju teksta kao cjeline $^{24}$. Motiv prokletstva i ime kao predmeti naše analize mogu se smjestiti na semantičku razinu analize budući da pokušavamo odgonetnuti načine na koje je moguće interpretirati značenje imena kao simbola i performativnih iskaza te njegovu povezanost s interpretacijom teksta u cjelini.

Potrebno je istaknuti i manjkavosti takvog pristupa kakvog zagovara Austin i primijeniti određene modifikacije. Naime Austin je u performativnu teoriju ugradio preveliku ulogu autora i njegove intencije. To znači da je značenje koje će proizaći iz samog iskaza u velikoj mjeri ovisilo o namjeri autora samog iskaza. Terry Eagleton smatra da je tako postavljena teorija nezdravo pravnička: daje preveliku važnost subjektu koji iskaz

\footnotetext{
${ }^{23}$ Ibidem, str. 19.

${ }^{24}$ J. Butler, op. cit.
} 
izgovara i konvencionalnim uvjetima pod kojima ga izgovara ${ }^{25}$. Performativnu teoriju, naročito u našem slučaju, treba prilagoditi uvažavajući mogućnost da tekst u procesu čitanja sugerira određena značenja koja izmiču autorovoj intenciji. Također, kada se motiv prokletstva kao nasljedne kategorije koja se prenosi preko imena uklopi u kontekst recepcije samog teksta, interpretacija se dalje uslojava. Naime kontekst je nedavno završen ratni sukob na južnoslavenskim prostorima s još svježim posljedicama. Na njega se nadovezuju još nerazriješena pitanja krivnje i uzroka sukoba, kao i trajna napetost između etničkih identiteta. Uklapanjem u takav kontekst recepcije, ime kao simbol proklizava u novo označeno.

Kako se napokon manifestira performativna dimenzija imena u samom tekstu? Prvo treba napomenuti da ime ne samo da potvrđuje tragediju, kao klasični performativ, nego ono samo jest tragedija. U Jergovićevim pripovijetkama moguće je pronaći primjere u kojima se imenom priziva već formirana tragedija ili je u samom imenu sadržaj potencijal za formiranje tragedije. Ta se imena dodjeljuju subjektima iako se strahuje (strah koji se ne izgovara, nego se može iščitati posredno) od tragedije koju bi mogli ponoviti. I ta imena na kraju ispunjavaju svoju svrhu, dozivaju tragediju i ispunjavaju prokletstvo. Dakle, poput performativa imena kreiraju, utvrđuju stanje ili radnju ${ }^{26}$. U sljedećem primjeru ime ne samo da nagovještava, nego se poistovjećuje s tragedijom. U priči Jid govori se o Savi Turudiji Kostiću čije se ime pojavljuje samo jednom, samo je jedan pisani trag o postojanju tog čovjeka. A taj trag je članak u crnoj kronici

${ }^{25}$ T. Eagleton, op. cit., str. 133.

${ }^{26}$ Kada je u pitanju razmatranje odnosa imena i performativa, neizbježno je uključiti u raspravu kartezijansko viđenje subjekta. Naime prema toj perspektivi subjekta ne definira zamjenica Ja, što bi se u našem kontekstu moglo poistovjetiti s imenom. To je statična kategorija, pa se inzistira na cogito, glagolu mislim. Dakle, radi se o subjektu koji se realizira tek u formulaciji Ja mislim jer je ovdje uključena radnja, čin, djelatni subjekt (subjekt koji se realizira djelovanjem). Ovdje je glagol mislim u specifičnom značenju jer ima potencijalnu performativnu dimenziju (iako to moramo uzeti sa zadrškom budući da postoje brojne nedoumice oko ove konstatacije, tj. podrazumijeva li izgovaranje tog glagola i stvarni akt mišljenja?) (A. Banfield, The name of the subject - the „II”, ,Yale French Studies" br. 93, 1998). Prevladava li možda taj jaz, između statičnog subjekta obilježenog samo imenom i ,punog" subjekta koji djeluje, upravo ime koje ima performativnu dimenziju? 
o prometnoj nesreći u kojoj je Sava poginuo ${ }^{27}$. Nema osmrtnice, nikakvog dokumenta, samo mali zapis u rubrici novina u kojoj se, simbolično, objavljuju samo tragedije. Tu se ime potpuno poistovjetilo s tragedijom.

U priči Halal Salko je nositelj tragične sudbine koja se dogodila njegovoj obitelji. Pijani brat ubio je oca sjekirom, a Salko preuzeo njegovu krivicu jer, za razliku od brata, nema djecu koja će ostati za njim gladna dok je u zatvoru. On priča svoju priču iz groba, gubi se, jedino za što se ima uhvatiti je vlastito ime. Zna da je ono prokleto, da je uz njega vezana samo tragedija, ali ga i dalje ponavlja. I ponavljat će ga uvijek, da se ne izgubi, jer ne želi bježati od činjenice da je njegov cijeli život tragičan slijed događaja ${ }^{28}$. Svakim se ponavljanjem tog imena potvrđuje/stvara svijest o neizbježnoj tragediji koja se ovdje prožima sa samim životom aktera kao cjelinom. Izgovaranje imena potvrđuje tragediju, tj. njegovo postojanje kao subjekta, u čemu je evidentna performativna dimenzija imena. U priči Gurbet, glavni junak nosi ime koje u prijevodu glasi nedostatak ili greška. On je sam utjelovljenje nesreće koja je upisana u njegovo ime od rođenja. U početku, tu nesreću izaziva u drugima iz svoje okoline koji su ga slučajno pogledali. Za njega samog ime će označiti i ispuniti tragediju kada ugleda Zumru. Ali to je samo vanjski poticaj sjemena tragedije koja je već usađena ${ }^{29}$.

U ovoj smjeloj interpretaciji modificirana je definicija performativa. Dok se u klasičnom smislu tog pojma podrazumijevao glagol (uzimam, obećajem, potvrđujem), ovaj rad postavlja tezu o performativnosti samog imena. Izgovor imena ne upućuje poput glagola na konkretnu radnju, nego je ovdje performativna dimenzija uočljiva na apstraktnijoj razini. U isrcpnom ocrtavanju semiotičkog polja imena kao simbola, uočen je motiv prokletstva koji se može interpretirati kao dio imena. Tako bi ponavljanje imena ponavljalo i samu kletvu, tj. zazivalo tragediju koja je u njega upisana. Ako je spomenuti Salko iz priče Halal dobio ime po ujaku koji je umro mlad, onda će i ponavljanje tog imena (ponovno imenovanje mladog Salke istim imenom) opet, u toj produženoj performativnoj dimenziji, prizvati i proizvesti tragediju (kao što izgovor glagola proklinjem te uspostavlja kletvu).

\footnotetext{
${ }^{27}$ M. Jergović, op. cit., str. 239.

${ }^{28}$ Ibidem, str. 119.

${ }^{29}$ Ibidem, str. 14.
} 


\section{Zaključak}

Ovom analizom iscrpljen je barem dio semiotičkog polja imena u zbirci priča Miljenka Jergovića Inšallah, Madona inšallah. U tim su tekstovima imena točke u kojima se umnažaju moguće interpretacije. U radu se pokušalo dekodirati kod u kojem imena kao simboli imaju funkciju poput aksioma s nedjeljivim početnim značenjem. A početno značenje smo odredili kao motiv prokletstva koje se nasljeđuje preko imena. To je rezultat naglašeno fatalističkog stava pripovjedača po kojem su njegovi akteri predodređeni za tragediju; oni su je naslijedili, preuzeli i ona čini sastavni dio njihove identitetske strukture. Iako od te tragedije na kraju stradavaju (prokletstvo se uvijek ispunjava), oni ne bježe ni od njega, ni od svog imena. Jer, tragedija - to su oni sami. Bez nje ne bi imali niti jednu čvrstu točku na koju bi se oslonili. Gotovo da je cilj njihovog života ispuniti tragediju, tj. ono što im je upisano u ime koje nose. Izgovaranjem imena potvrđuje se neizbježnost tragedije i ona se dijelom ispunjava (priziva) ponavljanjem tog imena. Ta performativna snaga imena završni je dio ciklusa koji dovodi do propasti subjekta.

Ovdje možemo povući granicu iščitavanja kao da smo došli do valjanog zaključka, iako je ta granica na kojoj smo stali sasvim proizvoljna. Time nikako nisu iscrpljeni svi interpretacijski potencijali imena kao simbola u odabranim Jergovićevim tekstovima. Već je naznačeno kako dodatnu dimenziju čitanja otvara i uključivanje konteksta recepcije djela u analizu (poratno razdoblje u novom tisućljeću). Stoga bi se ovaj niz svakako mogao nastaviti: ime - simbol - prokletstvo - naslijeđe - performativ tragedije - kontekst - rat - pitanje uzroka - neizbježnost sudbine - rasplinuta krivnja... Zadnje tri stavke zacrtavaju mogući smjer interpretacije suvremenom čitatelju obilježenim ili pak upoznatim s kulturalnim kodom južnoslavenskih prostora $s$ kraja dvadesetog i početka dvadeset i prvog stoljeća. To je interpretacija na koju tekst ne upućuje neposredno, ali ostavlja prostora za njenu mogućnost.

Kao što tvrdi Jacques Derrida, nema konačnog ili finalnog označenog izvan sustava semiotičkih razlika jer svako značenje upućuje na ostale znakove, u čemu i samo postaje označiteljem. U tom je sustavu značenje neprestano odgađanje ${ }^{30}$. Ovdje smo suočeni s tipičnim primjerom teksta

\footnotetext{
${ }^{30}$ W. Nöth, Priručnik semiotike, prev. A. Stamać, Zagreb 2004, str. 54.
} 
koji sugerira složenu višeznačnost (što je odlika kvalitetne književnosti). Njime smo uvučeni u hrvanje s tekstom koji neprestano proizvodi. Julija Kristeva smatra da književni tekst nije produkt, nego proces. Tekst je nešto „proizvodno, proizvođeće” ${ }^{\text {"31 }}$. Mi smo se do neke granice „igrali” s njime, otkrili čari i bogatstva te igre, ali povukli nekakvu granicu da bismo mogli na kraju završiti s nekim rezultatom. A taj je rezultat jedna zanimljiva interpretacija.

\footnotetext{
${ }^{31}$ Ibidem.
} 
